The Canadian Mineralogist

Vol. 42, pp. 1205-1219 (2004)

\title{
NEW CHEMICAL DATA ON THE CLINOPYROXENE-GARNET PAIR IN THE ALPE ARAMI ECLOGITE, CENTRAL ALPS, SWITZERLANDף
}

\author{
RosANGELA BOCCHIO ${ }^{\S}$ AND LUISA DE CAPITANI \\ Dipartimento di Scienze della Terra “Ardito Desio”, Università degli Studi di Milano, \\ Via Botticelli 23, I-20133 Milano, Italy \\ LUISA OTTOLINI \\ C.N.R. - Istituto di Geoscienze e Georisorse (IGG), Sezione di Pavia, Via Ferrata 1, I-27100 Pavia, Italy
}

\begin{abstract}
In the area of Gorduno, near Bellinzona, Central Alps, Switzerland, well-preserved eclogites crop out only at the margin of the garnet peridotite massif of Alpe Arami (AA). These bodies of eclogite were not derived from cognate mafic layers of mantle origin, and their thermal evolution is different from that inferred for the peridotite. Some questions are still open about the P-T evolution of AA eclogites, and the data given in literature cover a broad range of variation. We have investigated the bulk composition and the clinopyroxene-garnet trace-element distribution in a sample of eclogite from a lens occurring at the rim of the peridotite body. We report new data on trace elements in the bulk rock, obtained by ICP-MS, as well as the results of SIMS analyses on REE, Ti, V, Cr, Y, Sr, Zr, Sc carried out on the two major rock-forming minerals, i.e., clinopyroxene and garnet. We also provide $\mathrm{AAS}$ data for $\mathrm{Co}, \mathrm{Ni}$ and $\mathrm{Cu}$ in purified clinopyroxene and garnet concentrates, and $\mathrm{O}$ isotope ratios both on the bulk rock and on clinopyroxene and garnet. We found that: i) the trace-element abundance in garnet and clinopyroxene may be strongly influenced by the major-element composition; ii) their distribution within both mineral phases is inhomogeneous. In particular, their highly variable contents highlight the complex evolution of the AA eclogite and emphasize the existence, at least for some elements and at a very local scale, of chemical disequilibrium, also confirmed, in an independent way, by a significant difference in $\delta^{18} \mathrm{O}$ between clinopyroxene and garnet. Therefore, the low temperature of equilibration estimated in eclogite sample 70-AM-10 is not an artifact of the computational strategy adopted, but is the record of the lack of complete equilibration between clinopyroxene and garnet with changing P-T conditions during the various metamorphic events.
\end{abstract}

Keywords: eclogite, garnet, clinopyroxene, SIMS data, trace elements, oxygen isotope data, Alpe Arami, Central Alps, Switzerland.

\section{SOMMAIRE}

Des éclogites bien préservées affleurent dans la région de Gorduno, près de Bellinzona, Alpes centrales, en Suisse, mais seulement le long de la bordure du massif de Alpe Arami (AA) à péridotite grenatifère. Ces affleurements d'éclogite n'ont pas une dérivation par transformation de niveaux mafiques génétiquement liés à la péridotite dans le manteau, et leur évolution thermique diffère donc de celle déduite pour la péridotite. Certaines questions demeurent posées à propos de l'évolution P-T des éclogites de ce massif, et les données publiées font preuve d'une grande variabilité. Nous avons donc étudié la composition globale de ces roches et la distribution d'éléments traces entre les deux minéraux principaux, clinopyroxène et grenat, dans un échantillon d'éclogite provenant d'une lentille en bordure du massif péridotitique. Nos résultats portent sur la quantité des éléments traces dans la roche même, telles qu'indiquée par la méthode ICP-MS, de même que par analyses SIMS du clinopyroxène et du grenat portant sur les terres rares, Ti, V, Cr, Y, Sr, Zr, et Sc. De plus, nous présentons des données obtenues par absorption atomique sur le $\mathrm{Co}, \mathrm{Ni}$ et $\mathrm{Cu}$ dans des concentrés purifiés de clinopyroxène et grenat, et des rapports des isotopes obtenus pour décrire la roche globale et les deux minéraux. Nous trouvons que l'abondance des éléments traces dans le grenat et le clinopyroxène peut être fortement influencée par leur composition en termes des éléments majeurs; de plus, leur distribution dans ces deux minéraux est hétérogène. En particulier, leurs teneurs fortement variables soulignent l'évolution complexe de l'éclogite AA et l'existence, au moins pour certains éléments et à une échelle très locale, d'un déséquilibre chimique, que vient confirmer, de façon indépendante, une différence importante dans les valeurs $\delta^{18} \mathrm{O}$ entre le clinopyroxène et le grenat. C'est donc dire que la faible température de ré-équilibrage indiquée pour l'échantillon d'éclogite 70-AM-10 ne serait pas un artifice des méthodes de calcul employées, mais

I Dedicated to the memory of Giuseppe Rossi and Luciano Ungaretti.
$\S$ E-mail address: rosangela.bocchio@unimi.it 
plutôt un témoignage du manque d'équilibrage complet entre clinopyroxène et grenat à mesure que les conditions $\mathrm{P}-\mathrm{T}$ ont changé lors des divers événements métamorphiques.

(Traduit par la Rédaction)

Mots-clés: éclogites, grenat, clinopyroxène, données SIMS, éléments traces, données isotopiques sur l'oxygène, Alpe Arami, Alpes centrales, Suisse.

\section{INTRODUCTION}

The garnet peridotite massif of Alpe Arami (hereafter AA), part of the upper Pennine Cima Lunga Adula nappe complex, in the Central Alps of Switzerland, is accompanied at its margins and throughout the surrounding gneiss area by variably amphibolitized eclogites along the mountain slope down to Gorduno (Dal Vesco 1953, O’Hara \& Mercy 1966, Möckel 1969, Ernst 1977, Bocchio et al. 1985, Pfiffner \& Trommsdorff 1998, Tóth et al. 2000). However, fresh eclogite does occur, specifically in a layer surrounding the peridotite body.

In the present paper, we have investigated the bulk composition and the trace-element distribution between clinopyroxene and garnet in a sample of eclogite from Alpe Arami, labeled 70-AM-10. This sample displays a surprisingly low temperature of equilibration, estimated from the clinopyroxene-garnet pair: $\sim 480^{\circ} \mathrm{C}$ at $\mathrm{P}$ $=16 \mathrm{kbar}$ (Bocchio et al. 1985 ). Such a result contrasts with values of temperature given in the literature and reviewed below for the eclogitic rocks of this area (Bocchio et al. 1985). The trace-element concentrations, measured with SIMS, and the ensuing partition-coefficients $\left(D_{\mathrm{i}}\right)$ between clinopyroxene and garnet, can provide fundamental insights into the rock's history, with particular reference to the petrogenetic processes involved in its evolution. In addition, we provide $\mathrm{O}$ isotope data both on the bulk rock and clinopyroxene and garnet single phases, and thus illustrate the key role of $\mathrm{O}$ isotopes in investigating near-surface processes.

\section{BACKGROUND INFORMATION}

Whereas an Eocene age is nowadays generally accepted for the high-pressure metamorphism that affected this mafic-ultramafic association ( $c a$.43-35 Ma: Becker 1993, Gebauer 1999), the origin and the metamorphic evolution of the AA peridotite are still matters of debate; indeed, there is a continuing controversy in the literature. O'Hara \& Mercy (1966), Ernst (1977, 1981), and Pfiffner \& Trommsdorff (1998) have proposed a mantle origin. In particular, the latter two authors suggested an origin in a subcontinental environment near the crust-mantle interface, in contrast with derivation from much greater depths (300-400 km) (Dobrzhinetskaya et al. 1996, Green et al. 1997a, b). The contrasting hypotheses on the P-T conditions experienced by the AA peridotite (Brenker \& Brey 1997,
Nimis \& Trommsdorff 2001a, b, Paquin \& Altherr $2001 \mathrm{a}, \mathrm{b})$ are due to strongly scattered T values determined by the application of various thermometers based on the partitioning of elements with different diffusivities. These features have been tentatively explained by Paquin \& Altherr (2001a, b) as a consequence of a lack of equilibration during metamorphic evolution. Reviews of the different viewpoints have been recently summarized by Paquin \& Altherr (2002) and by Olker et al. (2003).

The eclogites of this area are not derived from cognate mafic layers of mantle origin, and their thermal evolution is different from that inferred for the peridotite (Paquin \& Altherr 2001b). The data on the equilibration temperature of the AA eclogites reported in the literature were all obtained by applying classical geothermometers based on the distribution of $\mathrm{Fe}$ and $\mathrm{Mg}$ between the clinopyroxene and garnet core. They cover a broad range of variation, starting from the minimum conditions $\mathrm{T}=691^{\circ} \pm 31{ }^{\circ} \mathrm{C}$ for an assumed pressure of $2 \mathrm{GPa}$ (Woodland et al. 2002) up to an estimated peak temperature of $860-927^{\circ} \mathrm{C}$ at $\mathrm{P}$ of $18-20 \mathrm{kbar}$ (Brouwer 2000). Paquin \& Altherr (2001b) calculated a T range of $750-800^{\circ} \mathrm{C}$ for a nominal pressure of $3 \mathrm{GPa}(30 \mathrm{kbar})$, using the mineral compositions given by Ernst (1977). Slightly higher temperatures have been obtained by Brenker et al. (2003), who estimated a range of 800 $900^{\circ} \mathrm{C}$ for an assumed pressure of $1.5-2.5 \mathrm{GPa}$. On the basis of petrological studies of the mineral assemblages associated with omphacite containing oriented precipitates of $\mathrm{SiO}_{2}$, Dobrzhinetskaya et al. (2002) have concluded that the AA eclogites experienced at least four stages of mineral growth corresponding to a $\mathrm{P}-\mathrm{T}$ path with a metamorphic peak at $1100^{\circ} \mathrm{C}$ and $7 \mathrm{GPa}$. Recently, Ravna \& Terry (2004) applied a new thermobarometric method based on $\mathrm{Mg}, \mathrm{Ca}$ and $\mathrm{Al}$ end members (Grs-Prp-Di-Ms-Cel) in UHP and HP eclogites and schists, and estimated $676^{\circ} \mathrm{C}$ at $3.49 \mathrm{GPa}$ for the AA eclogite.

The AA suite of eclogites and eclogitic amphibolites has been investigated in several studies that focussed on the bulk and mineral chemistry (Grubenmann 1908, Dal Vesco 1953, O’Hara \& Mercy 1966, Bocchio 1975, 1977, Ernst 1977, Bocchio et al. 1978, 1985, Becker et al. 2000, Brouwer 2000). Very few trace-element data are available so far for the bulk rock and, to our knowledge, no in situ trace-element data were obtained in the two major rock-forming minerals, i.e., clinopyroxene and garnet in the AA suite. 


\section{Petrography of the Alpe Arami Eclogite}

Detailed petrographic investigations in the AA area led Bocchio et al. (1985) to recognize at least four stages of retrogression from eclogite to amphibolite. However, sensu stricto eclogites (i.e., rocks still preserving the primary eclogitic assemblage omphacite + garnet + rutile) crop out only in a layer surrounding the peridotite body. Eclogite 70-AM-10 occurs very near the contact with the peridotite massif (locality $a$ of Fig. 2 in Bocchio et al. 1985), but separated from it by a chlorite-bearing peridotite mylonite rim. It is a fresh eclogite, fine-grained and light green in color, composed chiefly of light pink garnet and light green clinopyroxene (omphacite). Garnet (30 vol.\%), in large subhedral grains, is usually cracked and surrounded by a thin kelyphitic rim of a green amphibole, which also fills the internal fractures. Clinopyroxene occurs as euhedral prismatic crystals (14 vol.\%) unevenly rimmed by a fringe of symplectite alteration (35 vol. \%) made up of a very fine intergrowth of radiating plagioclase and amphibole. Occasionally, omphacite and garnet are in mutual contact: in this case, the symplectite does not occur, and only a thin rim of amphibole separates the two minerals. Amphibole also is present as a primary mineral whose grains show straight boundaries with both omphacite and garnet. Both the primary and secondary amphibole (at the rim and in the cracks of garnet) are pargasitic in composition (Bocchio 1977); they amount to 14 vol.\%. Kyanite, rutile, plagioclase and opaque minerals occur as minor components (1-4 vol.\%). Epidote-group minerals are totally absent.

\section{AnAlytical Methods}

The eclogite sample $70-\mathrm{AM}-10$ has already been studied. The first author (Bocchio 1975, 1977, Bocchio et al. 1978, 1985) focussed on bulk composition and mineral chemistry, and Rossi et al. (1978) and Pavese et al. $(2000,2001)$ investigated the crystallography of the clinopyroxene. In the present work, the rare-earth elements (REE) and selected trace elements in the bulk rock were investigated by the ICP-MS technique at CRPG-CNRS (Vandoeuvre-lès-Nancy, France). Handpicked separate grains of garnet and clinopyroxene, embedded in epoxy resin, were analyzed in situ for major and minor elements with an ARL EMX-SEMQ electron microprobe (EMP) at CNR-IDPA (Milan), and for trace constituents (REE, Sc, Ti, V, Cr, Sr, Y, Zr) with a Cameca IMS 4f ion microprobe installed at CNR-IGG (Pavia). The analytical methods are described in Bocchio et al. (2000).

From the total major-element dataset, only those analyses that passed the reliability test were selected, i.e., those with formulae in agreement with all crystalchemical constraints, as suggested by Mottana (1986). The concentration of the first transition-series trace elements $\mathrm{Co}, \mathrm{Ni}$, and $\mathrm{Cu}$ have been determined on purified concentrates of the two minerals by atomic absorption spectrometry using the FAA and GFAA techniques, at the University of Milan; see Bocchio et al. (2000) for details. Additional information was derived from $\mathrm{O}$ isotope analyses performed on the bulk rock and separate grains of the two minerals with the $\mathrm{BrF}_{5}$ method using a MAT-251 EM mass spectrometer at the Institute of Mineral Resources of Beijing (China). We used the standard NBS-28 $\left(\delta^{18} \mathrm{O}_{\mathrm{V} \text { SMOW }}=9.6 \%\right)$; precision of analyses: $\pm 0.2 \%$ o $( \pm 1 \sigma)$.

\section{Results AND Discussion}

\section{Bulk composition of the rock sample}

The major-element data of Table 1 were obtained by classic wet-chemical methods (Bocchio 1975). The eclogite sample could represent a basaltic liquid with relatively low total alkali (3.37 wt\%), moderate $\mathrm{TiO}_{2}$ (1.28 wt \%) and $\mathrm{Al}_{2} \mathrm{O}_{3}(16.30 \mathrm{wt} \%)$, and an $\mathrm{Mg} \#$ value $\left[=100 * \mathrm{Mg} /\left(\mathrm{Mg}+\mathrm{Fe}^{2+}{ }_{\text {tot }}\right)\right]$ of 62.2 .

The abundances of the HFSE (Zr, Nb, Ti) and Y, which are commonly assumed to be immobile during ocean-floor alteration and metamorphic dehydration of mafic rocks (Pearce \& Cann 1973, Becker et al. 2000), suggest the derivation of sample 70-AM-10 from a MORB-like magma: in the multi-element diagram normalized to N-MORB (Pearce 1983), the concentration ratio is close to unity (Fig. 1a). This pattern matches that of the kyanite-bearing eclogite AA15 from the southwestern margin of the AA peridotite, analyzed by Becker et al. (2000). Figure 1a shows that both samples of eclogite have a MORB-like content of Th and Sm, confirming that the abundances of these elements in mafic high-pressure rocks reflect the original abundances in their protoliths (Becker et al. 2000). This is also the case of the mobile element $\mathrm{Sr}$, whose normalized concentration is close to one. This element plotted with $\mathrm{Ti}$ and $\mathrm{Zr}$ in the triangular diagram (not shown), proposed by Pearce \& Cann (1973) for unaltered rocks, gives further support to the inference that the eclogite protoliths are ocean-floor basalts. This inference is opposite to that made on the basis of $\mathrm{K}, \mathrm{Rb}$ and $\mathrm{Ba}$ abundances; their low contents compared to MORB ( $c f$. the average N-MORB data of Hofmann 1988) are consistent with their high mobility during metamorphic evolution.

The C1-normalized REE pattern (Fig. 1b) (factors from Anders \& Grevesse 1989) is nearly flat, with slight LREE depletion $\left[(\mathrm{La} / \mathrm{Yb})_{\mathrm{N}}=0.75\right]($ Table 1$)$. The total light rare-earth (LREE) content of the whole rock is higher than that in clinopyroxene and garnet, which display the familiar X-pattern (Griffin \& Brueckner 1985, Tribuzio et al. 1994, Bocchio et al. 2000). This result suggests that minerals other than clinopyroxene and garnet contribute to the whole-rock REE budget. In eclogite 70-AM-10, however, we found no accessory minerals, such as apatite and epidote, which are notori- 
ous in hosting a larger amount of REE (Grauch 1989, Tribuzio et al. 1994). It is therefore reasonable to infer that these elements may be incorporated in the amphibole, which occurs in significant amount (see above) both as a primary and a secondary mineral. In addition, we cannot disregard the possibility that some LREE might be also loosely held along intergranular films (Shatsky et al. 1990). As a concluding remark, note that the eclogite sample examined exhibits a $\mathrm{Sm} / \mathrm{Nd}$ ratio of 0.34 , which is very close to the value of 0.32 of presentday MORB (Sun \& McDonough 1989).
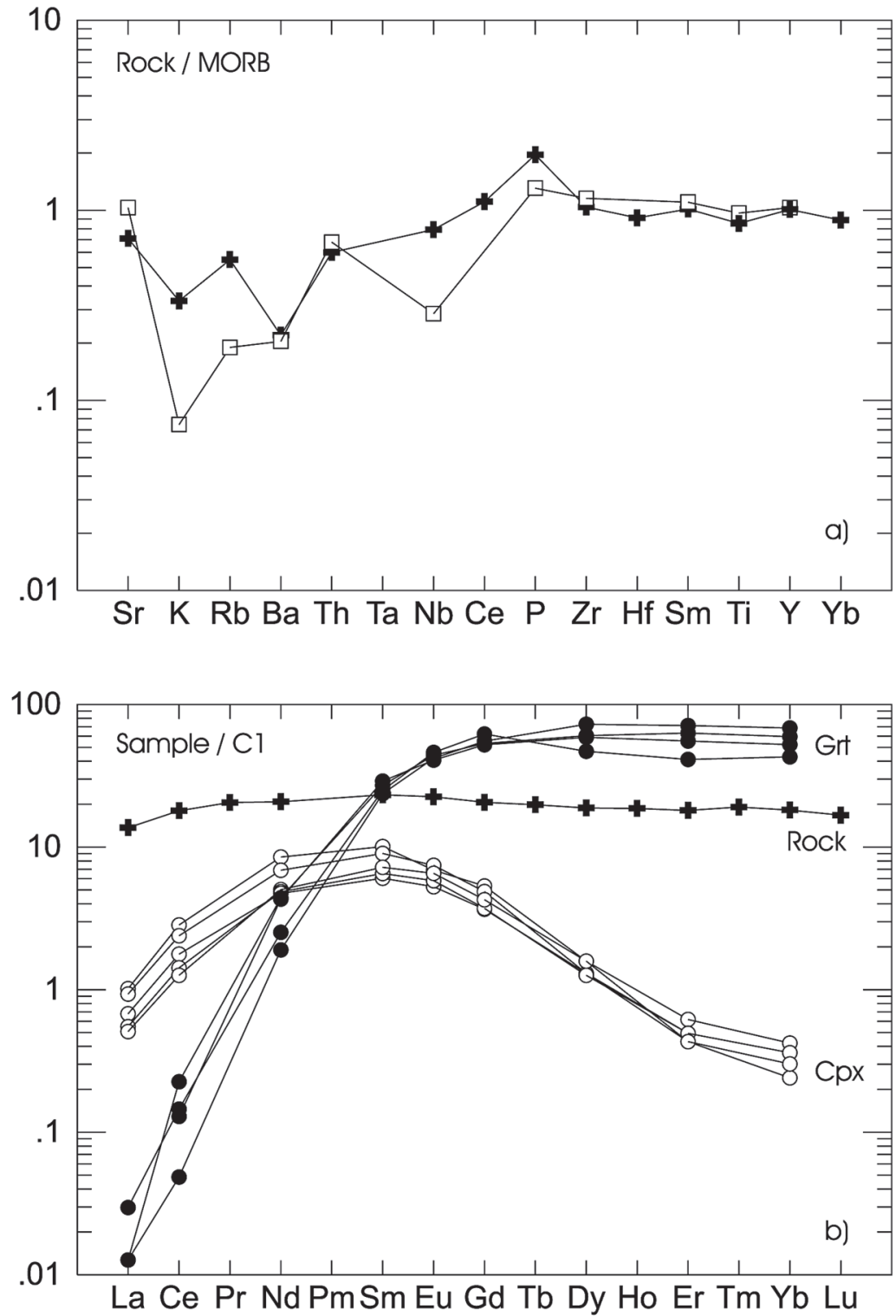

FIG. 1. a) Multi-element diagram normalized to N-MORB (Pearce 1983). Greek crosses: 70-AM-10 eclogite; squares: kyanite-bearing eclogite (AA15) from the southwestern margin of the Alpe Arami peridotite (Becker et al. 2000). b) REE abundances in 70AM-10 (whole rock) (Greek crosses) reported with those in selected grains of garnet (solid circles) and clinopyroxene (open circles) on a C1-normalized plot (Anders \& Grevesse 1989). 
The whole-rock $\delta^{18} \mathrm{O}$ value of $4.7 \%$ o determined for $70-\mathrm{AM}-10$ is lower (at the $1 \sigma$ level) than the estimated average value for the Earth's mantle $(5.5 \pm 0.4 \%$, Mattey et al. 1994) and the unaltered ocean-floor material (mean $\delta^{18} \mathrm{O}$ value close to $5.7 \%$, Muehlenbachs 1986), but it is comparable within error to the value of $4.8 \pm 0.9 \%$, determined in eclogitic Alpine gabbros that have undergone high-T ocean-floor alteration (Barnicoat \& Cartwright 1997). On the other hand, a relatively low $\delta^{18} \mathrm{O}$ value is not surprising because, as reported by Vogel \& Garlick (1970), such a feature is common in many eclogites of medium-temperature origin, including those from northwestern Spain, western France, southern Germany, Poland and western Norway. Whole-rock $\delta^{18} \mathrm{O}$ values lower than that of uncontaminated mantle material have also been determined in more recent years by Agrinier et al. (1985) and Miller et al. (1988) for some eclogites from the Western Gneiss Region (Norway) and from Koralpe and Saualpe (Austria), respectively.

\section{Chemical Composition of the Garnet}

Major-element data are reported in Table 2 as the average result of EMP analyses performed at the core of grains selected on the basis of the absence of evident optical inclusions and microcracks. The compositional variation detected from grain to grain is within the limit of the analytical error, except for $\mathrm{Mg}$ and $\mathrm{Ca}$ (> 5\% relative). All grains are members of the almandine - pyrope - grossular solid-solution series, with minor amounts of spessartine and andradite. The average composition, $\mathrm{Alm}_{40.8} \operatorname{Prp}_{36.6} \mathrm{Grs}_{21.0} \mathrm{Sps}_{1.0} \mathrm{And}_{0.6}$, is comparable with $\mathrm{Alm}_{43.7} \operatorname{Prp}_{33.9} \mathrm{Grs}_{17.1} \mathrm{Sps}_{1.6} \mathrm{And}_{3.7}$, obtained for the core zone of grains in thin section $70-\mathrm{AM}-10$ by Bocchio et al. (1985). These data are also consistent with the composition reported by Brouwer (2000, average composition of five samples: $\mathrm{Alm}_{39} \mathrm{Prp}_{35} \mathrm{Grs}_{21} \mathrm{Sps}_{1} \mathrm{Adr}_{4}$ ), and Woodland et al. (2002, sample AA1: $\mathrm{Alm}_{41 .}{ }_{9} \operatorname{Prp}_{33.2}$ $\mathrm{Grs}_{22.6} \mathrm{Sps}_{1.1} \mathrm{Adr}_{1.1}$ ) for garnet from kyanite-bearing eclogites from the southwestern margin of the AA peridotite.

The SIMS data for the REE and other trace elements ( $\mathrm{Sc}, \mathrm{Ti}, \mathrm{V}, \mathrm{Cr}, \mathrm{Sr}, \mathrm{Y}, \mathrm{Zr}$ ), measured on the same mount used for EMP analyses, are reported in Table 3, together with data for $\mathrm{Co}, \mathrm{Ni}$, and $\mathrm{Cu}$, obtained by $\mathrm{AAS}$ on a mineral concentrate. The C1-normalized trace-element patterns are reported in Figures $1 \mathrm{~b}$ and $2 \mathrm{a}$. The present dataset (Fig. 2a) is compared with that previously obtained by SIMS on garnet in an eclogite-amphibolite suite tectonically emplaced within the Adula Nappe gneisses at Soazza (Mesolcina Valley), $22 \mathrm{~km}$ to the northeast (Bocchio et al. 2000, and unpublished SIMS data on $\mathrm{Ti}, \mathrm{Cr}$, and $\mathrm{V}$, available from the authors on request).

Inspection of the C1-normalized REE data (Figs. 1b, 2a) shows that the patterns are qualitatively similar, all grains being enriched in the medium (MREE) and heavy rare-earths (HREE) relative to the LREE $\left[\left(\mathrm{Ce}_{\mathrm{N}} / \mathrm{Sm}_{\mathrm{N}}\right)\right.$ between 2 and $8 \times 10^{-3}$ for $23.68<\mathrm{Sm}_{\mathrm{N}}<29.03 ;\left(\mathrm{Ce}_{\mathrm{N}} /\right.$ $\mathrm{Yb}_{\mathrm{N}}$ ) between 1 and $4 \times 10^{-3}$, for $\left.43.01<\mathrm{Yb}_{\mathrm{N}}<68.43\right]$. Such a pattern confirms the well-established preference of the HREE for garnet (Mysen 1978). The intergrain variation, however, is higher than our typical SIMS analytical precision for REE, as derived from measurement reproducibility on international standards, which is on the order of $\sim 10 \%$ at $0.1-0.7 \mathrm{ppm}$ level (Bottazzi et al. 1994). Thus the observed scatter is ascribed to a real inhomogeneity within the set; $\Sigma$ REE varies from 45 to $58 \mathrm{ppm}$, with a mean value of $52 \mathrm{ppm}$. This holds, in the present case, for the MREE and HREE, whereas for the LREE, the major uncertainties in the SIMS analysis are derived from the low counting statistics owing to their extremely low concentrations (especially for La).

A careful inspection of Figure 2 a shows that the garnet in 70-AM-10 is less HREE-enriched than that in the samples from the omphacite-free symplectitic amphibolite (78-AM-13) from the Soazza suite and from an eclogite from the same suite with a lower proportion of clinopyroxene (78-AM-6), but it has a LREE content slightly higher than all other samples.

In Figure $2 \mathrm{a}, \mathrm{Y}$ is plotted in the position occupied by Ho, owing to their similarity in atomic radius. In the present case, it is positively correlated with the $\Sigma$ REE $(\mathrm{r}=0.98)$ and exhibits contents in the range 61.6-96.1 $\mathrm{ppm}$, with a mean value of $79 \mathrm{ppm}$. All $\mathrm{Y}$ values are in the range obtained for the garnet from Soazza $(62<\mathrm{Y}<$ $301 \mathrm{ppm})$.

Like the REE and Y, the large cation $\mathrm{Sr}$ is inferred to enter the eightfold-coordinated $X$ site of a garnet. Its content in the 70-AM-10 garnet is rather low (0.12$0.34 \mathrm{ppm})$. The scatter is quite large and may also be affected by low counting-statistics. As a whole, however, the Sr content seems to be of the same order as that in samples of garnet from Soazza (which typically have $0.1 \mathrm{ppm} \mathrm{Sr}$ where clinopyroxene is present), and lower than the value of $4 \mathrm{ppm}$ obtained for the omphacite-free symplectitic amphibolite at that local-

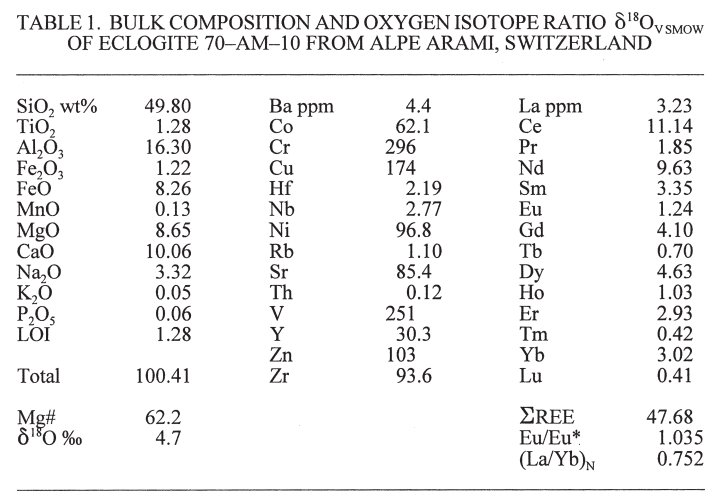

Explanation: $\mathrm{LOI}=$ loss on ignition; $\mathrm{Mg} \#=100 \mathrm{Mg} /\left(\mathrm{Mg}+\mathrm{Fe}^{2+}{ }_{\text {tot }}\right)$. The majorelement data are taken from Bocchio (1975). 


\begin{tabular}{|c|c|c|c|c|c|c|c|c|c|c|c|}
\hline & $\underset{(6)^{*}}{\operatorname{average}}$ & st.dev. & $\begin{array}{c}2 \\
\text { core } \\
(6)^{*}\end{array}$ & & ${ }_{(13)^{*}}^{\text {average }}{ }^{3}$ & st.dev. & $\begin{array}{c}4 \\
\text { core } \\
(3)^{*}\end{array}$ & $\begin{array}{c}5 \\
\text { rim } \\
(2)^{*}\end{array}$ & $\begin{array}{c}6 \\
\text { sympl. } \\
(1)^{*}\end{array}$ & 7 & 8 \\
\hline $\begin{array}{l}\mathrm{SiO}_{2} \text { wt } \% \\
\mathrm{TiO}_{2} \\
\mathrm{Al}_{2} \mathrm{O}_{3} \\
\mathrm{FeO} \\
\mathrm{MnO} \\
\mathrm{MgO} \\
\mathrm{CaO} \\
\mathrm{Na}_{2} \mathrm{O}\end{array}$ & $\begin{array}{c}39.56 \\
0.02 \\
22.47 \\
19.2 \\
0.49 \\
9.8 \\
8.05\end{array}$ & $\begin{array}{l}0.11 \\
0.01 \\
0.09 \\
0.19 \\
0.04 \\
0.53 \\
0.69\end{array}$ & $\begin{array}{c}39.4 \\
0.0 \\
23.0 \\
19.9 \\
0.82 \\
9.6 \\
8.2\end{array}$ & & $\begin{array}{c}55.46 \\
0.09 \\
12.39 \\
2.76 \\
0.03 \\
8.79 \\
12.7 \\
7.19\end{array}$ & $\begin{array}{l}0.44 \\
0.04 \\
0.39 \\
0.16 \\
0.02 \\
0.3 \\
0.35 \\
0.23\end{array}$ & $\begin{array}{c}55.1 \\
0.16 \\
12.9 \\
3 \\
0.09 \\
8.5 \\
13.4 \\
7.1\end{array}$ & $\begin{array}{c}54.6 \\
0.14 \\
12.4 \\
3.4 \\
0.08 \\
9 \\
14.4 \\
6.5\end{array}$ & $\begin{array}{c}54.4 \\
0.16 \\
9.9 \\
3.6 \\
0.09 \\
10.7 \\
17.0 \\
5.1\end{array}$ & & \\
\hline Total & 99.59 & & 100.92 & & 99.41 & & 100.25 & 100.52 & 100.95 & & \\
\hline $\begin{array}{l}\delta^{18} \mathrm{O} \% \% \\
X_{\mathrm{Ca}}\end{array}$ & $\begin{array}{l}4.6 \\
0.217\end{array}$ & & 0.223 & & 5.1 & & & & & & \\
\hline $\begin{array}{l}\mathrm{Si} \text { apfu } \\
\mathrm{IV}_{\mathrm{N}} \mathrm{Al} \\
\mathrm{V}^{\mathrm{Al}} \mathrm{Al} \\
\mathrm{Ti}^{3} \\
\mathrm{Fe}^{3+} \\
\mathrm{Fe}^{2+} \\
\mathrm{Mn} \\
\mathrm{Mg} \\
\mathrm{Ca} \\
\mathrm{Na}\end{array}$ & $\begin{array}{l}2.992 \\
0.008 \\
1.995 \\
0.001 \\
0.011 \\
1.204 \\
0.031 \\
1.105 \\
0.652\end{array}$ & & $\begin{array}{l}2.947 \\
0.053 \\
1.975 \\
0.000 \\
0.078 \\
1.167 \\
0.052 \\
1.071 \\
0.657\end{array}$ & & $\begin{array}{l}1.961 \\
0.039 \\
0.477 \\
0.002 \\
0.051 \\
0.031 \\
0.001 \\
0.463 \\
0.481 \\
0.493\end{array}$ & & $\begin{array}{l}1.937 \\
0.063 \\
0.471 \\
0.004 \\
0.068 \\
0.020 \\
0.003 \\
0.445 \\
0.505 \\
0.484\end{array}$ & $\begin{array}{l}1.921 \\
0.079 \\
0.435 \\
0.004 \\
0.079 \\
0.021 \\
0.002 \\
0.472 \\
0.543 \\
0.443\end{array}$ & $\begin{array}{l}1.920 \\
0.008 \\
0.332 \\
0.004 \\
0.089 \\
0.017 \\
0.003 \\
0.563 \\
0.643 \\
0.349\end{array}$ & $\begin{array}{l}0.47 \\
\\
0.05 \\
0.02 \\
\\
\\
0.46 \\
0.48 \\
0.52\end{array}$ & $\begin{array}{l}1.97 \\
0.03 \\
0.48 \\
0.06\end{array}$ \\
\hline \multicolumn{12}{|c|}{ End-member components of garnet and clinopyroxene } \\
\hline $\begin{array}{l}\text { Alm } \\
\text { Prp } \\
\text { Grs } \\
\text { Sps } \\
\text { Adr }\end{array}$ & $\begin{array}{c}40.8 \\
36.6 \\
21 \\
1 \\
0.6\end{array}$ & & $\begin{array}{r}43.7 \\
33.9 \\
17.1 \\
1.6 \\
3.7\end{array}$ & $\begin{array}{r}\mathrm{Jd} \\
\mathrm{Ae} \\
\mathrm{Di} \\
\mathrm{Hd} \\
\mathrm{Fs}\end{array}$ & $\begin{array}{r}44.3 \\
5.1 \\
46.3 \\
1.8 \\
2.5\end{array}$ & & $\begin{array}{r}41.6 \\
6.8 \\
44.4 \\
2.2 \\
5\end{array}$ & $\begin{array}{c}36.4 \\
8 \\
47.2 \\
2.4 \\
6\end{array}$ & & & \\
\hline
\end{tabular}

Columns 1, 3: EMPA data on garnet and clinopyroxene (present work); columns 2, 4, 5, and 6: EMPA data on garnet and clinopyroxene from Bocchio et al. (1985); columns 7, 8: cation distribution in clinopyroxene derived from crystallographic refinement (Rossi et al. 1978, Pavese et al. 2001); $(n)^{*}$ number of analyses made. The formulae are calculated on the basis of eight (garnet) and four (clinopyroxene) cations.

ity. This confirms the preference of $\mathrm{Sr}$ for clinopyroxene, and its tendency to enter garnet only where clinopyroxene is lacking (O'Reilly \& Griffin 1995, Bocchio et al. 2000).

As for the other trace elements included in our dataset, those forming the "first transition series" (i.e., $\mathrm{Sc}, \mathrm{Ti}, \mathrm{V}, \mathrm{Cr}, \mathrm{Co}, \mathrm{Ni}, \mathrm{Cu}$ ) very likely enter the octahedral site $(Y)$ of the garnet structure. Their concentrations follow the sequence of abundance $\mathrm{Cr}>\mathrm{Ti}>\mathrm{Ni}>\mathrm{Sc}>$ $\mathrm{V}>\mathrm{Co}>\mathrm{Cu}$. Chromium content measured by SIMS varies from 243 to $738 \mathrm{ppm}$, which attests to a significant $\mathrm{Cr}$ inhomogeneity among the grains, as seen for other trace elements (e.g., REE). The higher abundance of $\mathrm{Cr}$ at AA in comparison with Soazza (unpubl. SIMS data: 45-326 ppm Cr) confirms the well-known positive correlation of $\mathrm{Cr}$ with the pyrope component, which is higher in the AA garnet (37 mol.\% Prp) than in all the other occurrences (17-33 mol.\% Prp).

The most important host of $\mathrm{Ti}$ in eclogites is rutile $\left(\mathrm{TiO}_{2}\right)$, which is also the most abundant and ubiquitous non-silicate mineral occurring in these rocks. From the literature data, small quantities of $\mathrm{Ti}$ are known to be incorporated into silicates. In the present case, Ti has been detected by EMP analyses of both garnet and clinopyroxene (Table 2), and of amphibole (Bocchio 1977). Ti contents derived from EMP data are very close to the detection limits of the instrument and did not allow us to evaluate the degree of heterogeneity within the dataset. The new SIMS data have confirmed the low concentration of $\mathrm{Ti}$ (Table 2), but also point out the scatter (184-270 ppm Ti) in its intergrain distribution. The samples from Soazza (Bocchio et al. 2000) are slightly enriched in this element, consistent with the inverse correlation between $\mathrm{Ti}$ and the pyrope content, as suggested by Rost \& Grigel (1964).

The AA garnet is also depleted in V (51.5-72 ppm) in comparison with the value of $743 \mathrm{ppm}$ detected in the omphacite-free symplectitic amphibolite mentioned above, as well as in garnet samples from other eclogites (72 < V < 245 ppm, unpubl. SIMS data). As observed by some authors (Bocchio et al. 2000, and references therein), the behavior of $\mathrm{V}$ mimics that of Ti: a decrease in pyrope component is accompanied by an increase in $\mathrm{V}$ content.

The Sc variation in the AA garnet is small (from 71.0 to $73.7 \mathrm{ppm} \mathrm{Sc}$ ) and within the limit of analytical preci- 
sion. The average obtained ( $72 \mathrm{ppm} \mathrm{Sc}$ ) is very close to that reported for garnet samples in eclogites $(65 \mathrm{ppm})$ in the early compilation of Goldschmidt \& Peters (1931). The relatively small ionic radius for $\mathrm{Zr}$ suggests that even this cation may be involved in substitutions at the $Y$ site. Some authors (e.g., Novak \& Gibbs 1971, Harte \& Kirkley 1997), however, have proved that in garnet, this cation prefers eightfold coordination, or even partitions between the $Y$ and $X$ sites. In the AA garnet, the $\mathrm{Zr}$ content is low (2.5-4.3 ppm). Nevertheless, it shows an intergrain variation comparable to that previously determined in the samples from Soazza.

The average contents of $\mathrm{Cu}, \mathrm{Co}$ and $\mathrm{Ni}$ in garnet, measured by AAS, are reported in Table 3. In terms of absolute values, $\mathrm{Cu}$ displays the lowest abundance (19 $\mathrm{ppm})$, and $\mathrm{Ni}$, the highest (104 ppm). It is not realistic to compare abundances with the data on garnet in the Soazza suite, because both span a large range $(23<\mathrm{Cu}$ $<3217$ ppm, $74<\mathrm{Ni}<2504)$, which probably reflects the presence of small inclusions of opaque minerals that

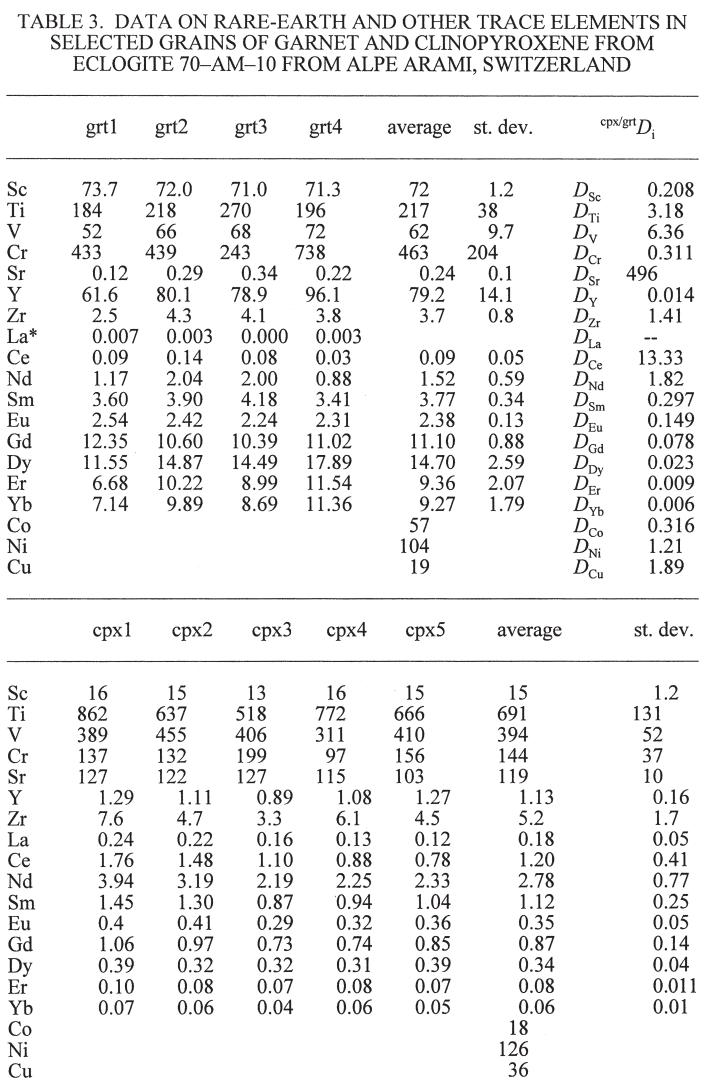

* These data are only indic ative, being comparable to SIMS data in analytical uncertainty. All data are derived by SIMS, except $\mathrm{Co}, \mathrm{Ni}$ and $\mathrm{Cu}$, obtained by AAS. The ${ }^{\mathrm{cpx} / \mathrm{grt}} D_{\mathrm{i}}$ partition coefficients, reported in the last column, must be considered as indicative only (see text). escaped our attention in an optical-microscope investigation (Bocchio et al. 2000). In contrast, the AA garnet has a Co abundance (57 ppm) falling within the range determined for garnet at Soazza (41-90 ppm).

The oxygen isotope ratio for AA garnet is $4.5 \%$ and is similar to that obtained for the whole rock $(4.7 \%$ ). This value is lower than the $\delta^{18} \mathrm{O}$ value $5.5 \pm 0.5 \%$ o commonly accepted for upper-mantle minerals ( $c f$. Nadeau et al. 1993) and beyond the range in $\delta^{18} \mathrm{O}_{\mathrm{grt}}(5.67-$ $7.18 \%$ ) measured by Kohn \& Valley (1998) in garnet from three eclogites samples from Trescolmen (Adula nappe), whose peak conditions of metamorphism have been determined to be in the range $550-650^{\circ} \mathrm{C}$ (Heinrich 1986). Values of $\delta^{18} \mathrm{O}$ lower than 5.5\%, however, are not unusual in garnet samples from European mediumtemperature eclogites e.g., Vogel \& Garlick (1970): $2.5 \%$ in eclogite from Weissenstein, Germany. Lower values $(5.19-5.58 \%$ ) were recently determined in garnet by Jacob \& Foley (1999).

\section{Chemical Composition of the Clinopyroxene}

Electron-microprobe data for the clinopyroxene in eclogite 70-AM-10 are reported in Table 2 as the average result of single-spot analyses performed at the core of the selected grains. The corresponding concentrations of the REE and other trace elements as determined with the SIMS instrument are shown in Table 3. Compositional variations have been detected from grain to grain both for major and trace elements, with the major-element variations within the limit of EMP errors for most elements, and higher for others, e.g., Fe ( $\sim \%$ relative). The clinopyroxene in our sample is an omphacite (nomenclature of Morimoto et al. 1988), with an ordered P2/n symmetry (Rossi et al. 1978, Pavese et al. 2000). The mean composition and formula are compared in Table 2 with the EMPA data determined by Bocchio et al. (1985), with their structural formulae recalculated. All the values reported for the omphacite core are within the standard deviation of the new analytical results, with the exception of a slight enrichment of $\mathrm{Ti}$ and $\mathrm{Mn}$. A regular enrichment of $\mathrm{Fe}, \mathrm{Mg}, \mathrm{Ca}$, and a depletion of $\mathrm{Al}$ and $\mathrm{Na}$ have been detected from core to the symplectitic rim. The pyroxene of the symplectite is confirmed to be omphacitic in composition, although depleted in the $\mathrm{Jd}$ component. All analyses of the core zone in clinopyroxene 70-AM-10 reveal a slight enrichment in $\mathrm{Na}$ and a depletion in $\mathrm{Ca}$, compared with other recent data on omphacite in the AA suite [Brouwer (2000): compositional range of five samples, 3.55-6.88 wt $\% \mathrm{Na}_{2} \mathrm{O}$, 13.13-17.68 wt\% CaO, 8.01-11.96 wt\% MgO, 2.49$6.01 \mathrm{wt} \% \mathrm{FeO}$; Woodland et al. (2002): sample AA1, 6.18 wt $\% \mathrm{Na}_{2} \mathrm{O}, 14.0$ wt $\% \mathrm{CaO}, 9.4$ wt\% $\mathrm{MgO}, 2.76$ wt\% FeO; Brenker et al. (2003): sample AAXB2, 5.34 wt $\% \mathrm{Na}_{2} \mathrm{O}, 14.08$ wt $\left.\% \mathrm{CaO}\right]$.

The composition of omphacite 70-AM-10, derived from the EPM data and from site-occupancy refinements carried out without any chemical constraint on selected 

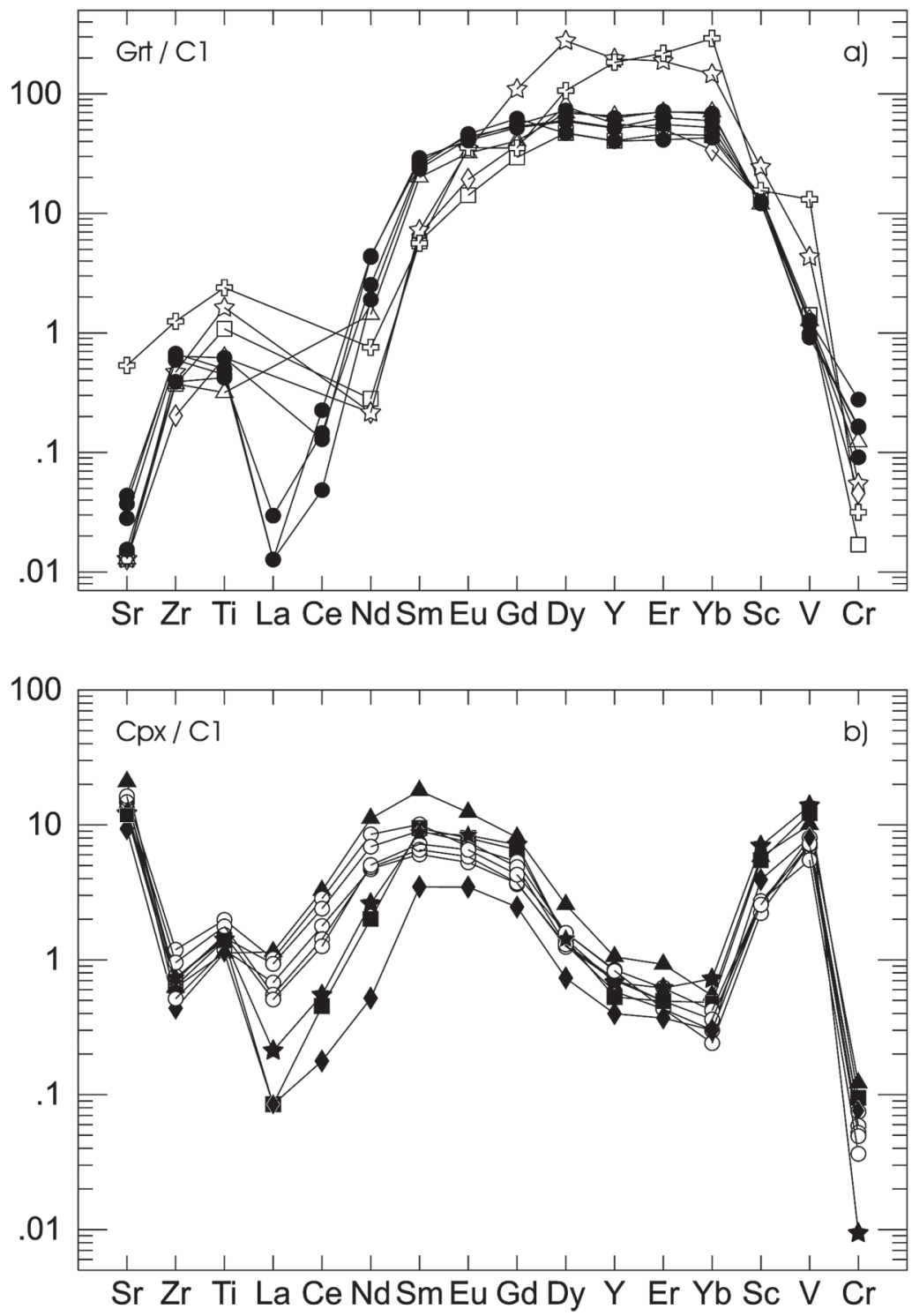

FIG. 2. C1-normalized (Anders \& Grevesse 1989) multi-element patterns for selected grains of garnet (a) and clinopyroxene (b) from eclogite 70-AM-10; symbols as in Figure 1b. For comparison, we have reported the data relative to garnet (a: open symbols) and clinopyroxene (b: full symbols) of the eclogites and symplectitic garnet amphibolite from Soazza (Bocchio et al. 2000). Explanations of symbols: triangles: 78AM-12, squares: 75-AM-47, diamonds: 75-AM-48, stars: 78-AM-6, and open Greek cross: 78-AM-13. See text for further details.

crystals by Rossi et al. (1978) and Pavese et al. (2000), is close to that of ideal omphacite $\left[\left(\mathrm{Ca}_{0.5} \mathrm{Na}_{0.5}\right)\right.$ $\left(\mathrm{Mg}_{0.5} \mathrm{Al}_{0.5}\right) \mathrm{Si}_{2} \mathrm{O}_{6}$ ], the proportions of $\mathrm{Ti}, \mathrm{Mn}$ and $\mathrm{Fe}$ in atoms per formula unit (apfu) being virtually negligible (Table 2, anal. 7-8).
The intergrain variation in REE content suggests a real inhomogeneity in the clinopyroxene core: $\Sigma$ REE varies from 5.71 to $9.39 \mathrm{ppm}$, with a mean value of 6.98 ppm. All the grains are characterized by a bell-shaped chondrite-normalized REE pattern, with a maximum at 
Sm (Fig. 1b), similar to those of omphacite samples from the Soazza suite (Fig. 2b). On the basis of ionic radius and crystal-structure refinements, Oberti \& Caporuscio (1991) suggested that the REE are hosted in the eightfold-coordinated $M 2$ site. Moreover, according to Caporuscio \& Smyth (1990), the REE incorporation in the $M 2$ site of $C 2 / c$ clinopyroxene is controlled by the electrostatic site-potential, which is inversely related to the amount of $\mathrm{Na}$ in this site. In $P 2 / n$ omphacite, the $M 2$ site is actually split into two sites ( $M 2$ and $M 21$ ), which have different geometrical features, over which $\mathrm{Ca}$ and $\mathrm{Na}$ are distributed more or less randomly (Rossi et al. 1983). Taking into account crystallographic and crystal-chemical data, R. Oberti (1999: pers. commun. of unpubl. data) and Bocchio et al. (2000) inferred that REE might be hosted preferentially in the smaller $M 2$ (Na-rich) site than in the larger M21 (Ca-rich) one. An $\mathrm{X}$-ray refinement of the structure and site-occupancy determination carried out on a representative crystal of omphacite 70-AM-10 (Rossi et al. 1978) gave the following distribution of $\mathrm{Na}$ and $\mathrm{Ca}$ in the eightfold-coordinated sites: $0.71 \mathrm{Na}+0.29 \mathrm{Ca}$ in $M 2$, and $0.33 \mathrm{Na}+$ $0.67 \mathrm{Ca}$ in $M 21$. This distribution differs very little from that in sample 75-AM-48 in the Soazza suite, which contains approximately $0.73 \mathrm{Na}+0.27 \mathrm{Ca}$ in $M 2$, and $0.29 \mathrm{Na}+0.72 \mathrm{Ca}$ in $M 21$, but that sample displays a level of $\Sigma$ REE lower than in clinopyroxene from Alpe Arami (Bocchio et al. 2000). Taking into account the study of Shearer et al. (1989), we tentatively suggest that the lower amount of $\mathrm{Na}$ (and the higher amount of Ca) at $M 2$ of omphacite from AA may indeed favor REE incorporation at this site. On this basis, it is correct to recall that subtle variations of REE concentrations in clinopyroxene could be due to competition with the cocrystallizing garnet (Oberti \& Caporuscio 1991), with a further contribution arising from minor or accessory minerals also crystallizing during the metamorphic evolution (Tribuzio et al. 1994, Bocchio et al. 2000).

Considering the ionic radii, $\mathrm{Y}$ and $\mathrm{Sr}$ are expected to enter the eightfold-coordinated sites (M2 and M21). In the clinopyroxene grains examined, $\mathrm{Y}$ is in the range $0.89-1.29 \mathrm{ppm}$, and $\mathrm{Sr}$, in the range 103-127 ppm. Both these elements display a rough positive correlation with ¿REE. Zirconium is commonly considered as an octahedrally coordinated cation. In the AA omphacite, $\mathrm{Zr}$ displays a more important intergrain variation (3.3-7.6 $\mathrm{ppm}$ ) than that determined in the omphacite from Soazza (2.8-4.7 ppm Zr).

The first-transition-series trace elements have the following sequence of relative abundance: $\mathrm{Ti}>\mathrm{V}>\mathrm{Cr}$ $>\mathrm{Ni}>\mathrm{Cu}>\mathrm{Co}>\mathrm{Sc}$. The absolute contents of the elements investigated by SIMS (i.e., Ti, V, Cr, Sc) are scattered, and intergrain variations in concentration (Table 3 ) are, with the exception of Sc, greater than the analytical uncertainty (see Bocchio et al. 2000 for details concerning the SIMS analyses).

All the transition elements considered are commonly regarded to enter the six-fold-coordinated $M 1$ site, where the four major cations $\left(\mathrm{Mg}^{2+}, \mathrm{Fe}^{2+}, \mathrm{Fe}^{3+}, \mathrm{Al}^{3+}\right)$ are also located, together with some minor cations $\left(\mathrm{Mn}^{2+}\right.$ and $\left.\mathrm{Ti}^{4+}\right)$. In $P 2 / n$ omphacite, the $M 1$ site is split into two independent sites, $M 11$ (Al-rich) and $M 1$ (Mgrich) (Rossi et al. 1983). From the site-occupancy refinement of the crystal of omphacite 70-AM-10 mentioned above, Rossi et al. (1978) deduced the following occupancies of major cations: $M 11=0.95 \mathrm{Al}+$ $0.03 \mathrm{Fe}^{3+}+0.02 \mathrm{Mg} ; M 1=0.90 \mathrm{Mg}+0.06 \mathrm{Fe}^{3+}+$ $0.04 \mathrm{Fe}^{2+}$. They concluded that in view of the small content of $\mathrm{Fe}$ (both $\mathrm{Fe}^{2+}$ and $\mathrm{Fe}^{3+}$ ), the sample has practically only $\mathrm{Al}$ in $M 11$ and $\mathrm{Mg}$ in $M 1$.

These observations confirm the well-known influence of the major-element population on the geometrical features of the structural sites. As a consequence, we can clearly infer that the incorporation of transition trace elements in the larger $M 1$ site or, alternatively, in the smaller $M 11$ sites, is constrained by both the variation of the main components and their charge and ionic radius. In particular, this is the case of Sc. This element occurs in the trivalent state $\left(\mathrm{Sc}^{3+}\right)$; in clinopyroxene, it has been described as substituting for ions such as $\mathrm{Fe}^{3+}$, $\mathrm{Al}, \mathrm{Cr}^{3+}, \mathrm{V}^{3+}$, and $\mathrm{Mn}^{3+}$ in the six-fold-coordinated sites, where it coexists with divalent ions as $\mathrm{Fe}^{2+}$ and $\mathrm{Mg}$ (Frondel 1968). Because of the resulting complexity of composition as well as the possible involvement of the coupled entrance of a monovalent ion at the $M 2$ sites, Frondel (1968) also suggested that it is difficult to state which ion is replaced by $\mathrm{Sc}^{3+}$. However, according to Messiga et al. (1995) and owing to its relatively large ionic radius (Shannon 1976), the incorporation of Sc in the octahedral sites could be reduced by the increased level of octahedral ${ }^{\mathrm{VI}} \mathrm{Al}$ due to solid solution toward Jd. In the present case, such a statement can indeed be supported: the AA omphacite has a Sc content (13-16 ppm) lower than the samples from Soazza (23-42 ppm), all of which show lower amounts of the Jd component.

The control of major elements on trace-element incorporation in the omphacite examined is also established for $\mathrm{V}$, the incorporation of which is dependent on its oxidation states $\left(\mathrm{V}^{3+}, \mathrm{V}^{4+}, \mathrm{V}^{5+}\right)$. The AA omphacite has a $\mathrm{V}$ content ( 311 to $455 \mathrm{ppm}$ ) lower than the range (457-787 ppm: unpubl. SIMS data) determined in the Soazza omphacites. These are also richer in $\mathrm{Fe}^{3+}(0.084$ 0.127 apfu) than the AA omphacite (Table 2), confirming the positive effect of the aegirine component on $\mathrm{V}$ incorporation already reported by Messiga et al. (1995) for the metamorphic clinopyroxenes of the Voltri Group. The positive correlation between $\mathrm{Fe}^{3+}$ and $\mathrm{V}$ suggests that this element is likely to be present as $\mathrm{V}^{3+}$; indeed the ionic radius of $\mathrm{V}^{3+}$ is very close to that of $\mathrm{Fe}^{3+}$ (Shannon 1976).

Chromium also is expected to occur as a trivalent ion: its concentration in AA omphacite varies from 97 to $199 \mathrm{ppm}$, i.e., within the range of the Soazza samples (25-324 ppm: unpubl. SIMS data).

In clinopyroxene, $\mathrm{Ti}$ is commonly expected to enter the octahedral site but, because of its fairly small ionic 
radius $\left(\mathrm{r}_{\mathrm{Ti}}=0.61 \AA\right.$ : Shannon 1976$)$ compared to typical $M 1$ cations $\left(\mathrm{Fe}^{2+}, \mathrm{Mg}, \mathrm{Fe}^{3+}, \mathrm{Cr}^{3+}\right)$, the possibility of its incorporation at the tetrahedral site cannot be disregarded. In any case, whatever may be its structural position, in most samples of omphacite it occurs as a minor element $\left(<0.5 \mathrm{wt} \% \mathrm{TiO}_{2}\right)$. The abundance of Ti determined by electron microprobe in the AA omphacite is relatively low $\left(0.09 \mathrm{wt} \% \mathrm{TiO}_{2}=540 \mathrm{ppm} \mathrm{Ti}\right)$ and falls in the range of variation $518-862 \mathrm{ppm}$ Ti obtained by SIMS on the same grains. The range of Ti concentration is even wider considering the EMPA data from Bocchio et al. (1985), reported for comparison in Table 2. The concentration of $\mathrm{Ti}$ is higher in AA omphacite than in coexisting garnet, but is lower than in amphibole interpreted as a constituent of the eclogitic assemblage (Bocchio 1977: 0.32 wt\% $\mathrm{TiO}_{2}=1918 \mathrm{ppm} \mathrm{Ti}$ ). SIMS Ti values (unpubl. data) in the range 489 to 614 ppm detected in the omphacite from Soazza show that Ti is more abundant in omphacite than in garnet. Such a result highlights the preference of this cation for clinopyroxene (and amphibole, if any), and it enters garnet readily only where clinopyroxene is lacking.

Cobalt, $\mathrm{Ni}$, and $\mathrm{Cu}$ have a dominantly divalent character. Thus, their content in the AA omphacite is lower (18 ppm Co, $126 \mathrm{ppm} \mathrm{Ni}, 36 \mathrm{ppm} \mathrm{Cu}$ ) than in the Soazza samples (20-52 ppm Co, 154-638 ppm Ni, 87-793 ppm $\mathrm{Cu}$ ). Bocchio et al. (2000) did not observe a regular relationship between them and the major divalent cations located in the octahedral sites. A similar conclusion is confirmed for the AA omphacite.

The omphacite $70-\mathrm{AM}-10$ gives a $\delta^{18} \mathrm{O}$ value of $5.1 \%$, which is higher than values pertaining to the whole rock and coexisting garnet, but is lower than the average oxygen isotopic composition of the clinopyroxene occurring in unaltered peridotite $\left(\delta^{18} \mathrm{O}=5.61\right.$ $\pm 0.32 \%$ : Mattey et al. 1994). Such a value is also lower than those (5.57-7.47\% ) measured by Kohn \& Valley (1998) for omphacite in the three samples of eclogite from Trescolmen mentioned above. It is, however, in the range (3.0-5.3\%o: Nadeau et al. 1993) in omphacites from the Monviso eclogitic rocks, which preserve the $\delta^{18} \mathrm{O}$ signature typical of an oceanic crust hydrothermally altered at a high temperature.

\section{Evaluation of Trace Element AND OXYGEN ISOTOPIC DisTRIBUTION Between Clinopyroxene and Garnet}

In the previous paragraphs, we have described the trace-element composition determined in garnet and clinopyroxene from the AA eclogite and shown that their abundance may be strongly influenced by the major-element composition. We have also pointed out that in most cases, their distribution within the two datasets is inhomogeneous. Such a chemical inhomogeneity is due to many factors, such as changes of $\mathrm{P}, \mathrm{T}$ and bulk composition, and also implies variation of diffusion rates during and after growth. Compared with major elements, the behavior of trace elements is a particularly sensitive indicator of changing conditions during metamorphism. In the present case, their highly variable contents highlight the complex evolution of the AA eclogite and emphasize the existence, at least for some elements and at a very local scale, of chemical disequilibrium. This inference supports the conclusion that the compositional variations for some trace elements determined both in omphacite and garnet obviously affect the reliability of the partition coefficients and renders unrealistic any calculation of $\mathrm{P}$ and $\mathrm{T}$ based on the exchange of these elements between the two minerals. With these words of caution in mind, we have reported in Table 3 the mean ratios $\left(D_{\mathrm{i}}={ }^{\mathrm{cpx}} \mathrm{C}_{\mathrm{i}} /{ }^{\text {grt }} \mathrm{C}_{\mathrm{i}}\right)$ for the REE and other trace elements.

The partition coefficients in the AA eclogite decreases quite abruptly with decreasing ionic radius, from $\mathrm{Ce}\left(D_{\mathrm{Ce}}=13.33\right)$ to $\mathrm{Yb}\left(D_{\mathrm{Yb}}=0.006\right)$, thus confirming the well-known greater affinity of the LREE for omphacite than for garnet. A similar feature was also determined in the Soazza eclogites: in particular, sample 78 -AM-48, showing $D_{\mathrm{Ce}}=11.00$ and $D_{\mathrm{Yb}}=0.009$, displays a pattern of distribution of REE between clinopyroxene and garnet very close to that determined in the AA sample.

The incorporation of LREE in clinopyroxene is indeed favored by the greater volume of its $M 2$ site relative to that of the $X$ site in garnet; on the contrary, garnet concentrates the smaller HREE more easily. However, owing to the greater thermal expansion of the clinopyroxene structure due to a higher number of shared edges of polyhedra (Novak \& Gibbs 1971), the ability of garnet to host the HREE decreases with increasing temperature. As a consequence, we find in the literature that eclogites of mantle origin, re-equilibrated at $\mathrm{T}>$ $1000^{\circ} \mathrm{C}$, invariably show $D_{\text {HREE }}$ values higher (Caporuscio \& Smyth 1990, Harte \& Kirkley 1997) than those obtained in AA as well as in eclogites that equilibrated at medium and low temperature ( $c f$. Messiga et al. 1995, Bocchio et al. 2000).

Summarizing the data reported in the literature and in this work, elements such as $\mathrm{Sr}, \mathrm{V}, \mathrm{Ni}$ and $\mathrm{Cu}$ preferably partition into clinopyroxene and display $D>1$ in high-, medium- and low-temperature eclogite; in contrast, Sc, Y, and Co invariably show a marked preference for garnet $(D<1)$ (Bocchio et al. 2000, and references therein). Titanium and chromium (usually considered as minor elements) show a slight preference for clinopyroxene but, in some eclogites of all three temperature ranges, they are evenly distributed between clinopyroxene and garnet $(D \geq 1)$. As already observed by Griffin et al. (1988) and O'Reilly \& Griffin (1995), the distribution of $\mathrm{Zr}$ is a sensitive indicator of changing T conditions; it enters garnet $(D<1)$ as $\mathrm{T}$ increases, e.g., in the high-temperature eclogites of mantle origin (Harte \& Kirkley 1997), as well as in the diamondiferous eclogite xenoliths from Udachnaya (Jacob \& Foley 1999). In low- and medium-temperature eclogites, $D_{\mathrm{Zr}}$ 
is either close to one (Messiga et al. 1995) or it exhibits a slight affinity for clinopyroxene (Bocchio et al. 2000, and present paper).

Differences in isotopic values between primary phases may provide valid information about the condition of equilibration of a rock. As for eclogites, some authors (e.g., Ongley et al. 1987, Caporuscio 1990, Leech \& Ernst 2000) suggest that convergence to zero or small differences between the $\delta^{18} \mathrm{O}$ values of garnet and clinopyroxene are consistent with the hypothesis that these phases achieved isotopic equilibrium; thus they imply that both minerals formed at the same time during the transition from basalt to eclogite.

The oxygen isotope fractionation calculated between omphacite and garnet $\left(\Delta_{\mathrm{cpx}-\mathrm{grt}}=\delta^{18} \mathrm{O}\right.$ of omphacite minus $\delta^{18} \mathrm{O}$ of garnet) in the AA eclogite is +0.6 . This value is high in comparison with the range (from -0.02 to +0.37 ) of isotopic fractionation between clinopyroxene and garnet determined in the Trescolmen eclogites, where these minerals have been proved to have crystallized contemporaneously and to have formed in isotopic equilibrium (Kohn \& Valley 1998). Smaller values of the range in $\Delta_{\mathrm{cpx} \text {-grt }}$ are also reported by Jacob \& Foley (1999: from +0.27 to +0.50$)$ and by Leech \& Ernst (2000: from +0.35 to +0.46 ). However, large differences in measured isotopic values between clinopyroxene and garnet are not uncommon in other eclogitic assemblages around the world, both of crustal and mantle origin [Vogel \& Garlick (1970, Fig. 2); Agrinier et al. (1985): from +0.1 to +1.5 ; Caporuscio (1990): from -0.6 to +0.6]. In particular, the last author suggested that the occurrence of a kelyphytic rim around garnet may have affected its isotopic value: as a consequence, a significant difference in $\delta^{18} \mathrm{O}$ between clinopyroxene and garnet may indicate disequilibrium. This inference could tentatively be applied to the AA sample, whose primary eclogitic assemblage shows the effects of a conversion to a late symplectitic amphibolite stage and resulting lower-grade assemblage: indeed, the early-formed garnet and clinopyroxene display at their rim incipient kelyphitic and symplectitic alteration, respectively. The regular decrease of $\mathrm{Na}$ and $\mathrm{Al}$, as well as the increase of $\mathrm{Fe}, \mathrm{Mg}$ and $\mathrm{Ca}$ from the clinopyroxene core to its symplectitic rim (Table 2: anal. 4, 5, 6) could indeed reflect re-equilibration of the major elements during the metamorphic evolution, but clearly it does not imply that this mineral is in isotopic equilibrium with the garnet. In addition, the early isotopic composition of both clinopyroxene and garnet may have been modified by large-scale transport of $\mathrm{H}_{2} \mathrm{O}$ provided by the adjacent, dehydrating metapelites during the late lowerpressure metamorphic event marked by the hydration of the mafic eclogites to amphibolites (Heinrich 1982).

\section{Concluding Remarks}

Bocchio et al. (1985) applied the classical geothermometers of Råheim \& Green (1974) and Ellis \&
Green (1979) based on the partition of $\mathrm{Fe}^{2+}$ and $\mathrm{Mg}$ between coexisting garnet and clinopyroxene and obtained a temperature of equilibration of $480^{\circ} \mathrm{C}$ for the eclogite 70-AM-10, which is lower than that reported in the literature for other samples in the area. They noted that this unrealistic value derives from the extremely low $\mathrm{Fe}^{2+}$ content of the clinopyroxene, although this mineral, on the whole, is not unusual in any other respect. Indeed, such a low $\mathrm{Fe}^{2+}$ may be biased because it is estimated indirectly on the basis of the crystal-chemical constraints suggested by the method adopted for the calculation of the structural formula. In the present case, however, the low $\mathrm{Fe}^{2+}$ has been confirmed first by crystallographic refinements (cf. Rossi et al. 1978) and, more recently, by X-ray and Mössbauer investigations (Pavese et al. 2000, unpubl. data). New EMPA data obtained for the core of clinopyroxene grains (see Table 2) confirm that the $\mathrm{Fe}$ content (both $\mathrm{Fe}^{3+}$ and $\mathrm{Fe}^{2+}$ ) is definitely low, and provide evidence of an intergrain $\mathrm{Fe}$ variation, which turns out to be higher than the analytical error. This leads not only to the possible outward diffusion of $\mathrm{Fe}$ (as proved by the slight increase of $\mathrm{FeO}$ determined in the symplectitic rim), but also it compromises the $\mathrm{Fe}-\mathrm{Mg}$ exchange thermometry between clinopyroxene and garnet. If the new data for eclogite 70-AM-10 are processed with the thermobarometric calibration proposed by Ravna (2000) and Ravna \& Terry (2004), and $\mathrm{Fe}^{3+}$ calculated from stoichiometry, the $\mathrm{P}-\mathrm{T}$ conditions of equilibration obtained are $542^{\circ} \mathrm{C}$ at $3.88 \mathrm{GPa}$, whereas if $\mathrm{Fe}^{3+}$ is calculated from $\mathrm{Fe}^{3+}=$ $\mathrm{Na}-(\mathrm{Al}+\mathrm{Cr})$, the conditions are estimated to be $729^{\circ} \mathrm{C}$ at $2.78 \mathrm{GPa}$ (Ravna 2004, pers. commun.). Mössbauer and micro-XANES studies of the omphacite are probably the only reliable method to overcome these uncertainties (Sobolev et al. 1999, Schmidt et al. 2003).

A further significant constraint on the estimated conditions of equilibration of eclogite 70-AM-10 comes from the oxygen isotope fractionation calculated between omphacite and garnet. Oxygen isotope thermometry (obtained through the courtesy of D. Jacob) based on $\delta^{18} \mathrm{O}$ fractionation between clinopyroxene and garnet yields a temperature of $1026^{\circ} \mathrm{C}$ using the method of Zheng (1993), which is considered accurate up to $1200^{\circ} \mathrm{C}$. The latter estimate is in good agreement with the highest recorded stage of metamorphism $\left(1100^{\circ} \mathrm{C}\right)$ calculated by Dobrzhinetskaya et al. (2002) for AA eclogites. However, compared with the data of Ravna (2004) indicating $542-729^{\circ} \mathrm{C}$, this result seems to be quite erratic and may confirm the suggestion that the pair is not in isotopic equilibrium. This result also contrasts with the $P 2 / n$ space-group symmetry of omphacite, indicating either formation at temperatures lower that the equilibrium temperature of the disordering reaction $\left(865 \pm 10^{\circ} \mathrm{C}\right.$ : Carpenter 1981) or a prolonged ordering process exceeding several million years at temperatures above the solvus $\left(300^{\circ} \mathrm{C}\right.$ : Champness 1973). An indirect confirmation of these inferences comes from a recent systematic study using 
transmission electron microscopy (TEM) performed on omphacite in eclogites from the Adula nappe. Brenker et al. (2003) found that the measured mean size of antiphase domains in omphacites from AA is not in agreement with high peak temperature $\left(850 \pm 50^{\circ} \mathrm{C}\right)$ that they had calculated for the $\mathrm{Fe} / \mathrm{Mg}$ exchange between clinopyroxene and garnet. The small size of the measured antiphase domains (APDs) in AA omphacite can be explained only if one assumes that the mineral started ordering at a temperature much lower than that of the $C 2 / c \rightarrow P 2 / n$ transition, i.e., possibly, during the retrograde Lepontine event that in the area reached peak temperatures around $650^{\circ} \mathrm{C}$ (Brenker et al. 2003). Such thermal conditions render more realistic the lower-temperature conditions estimated $\left(480-542^{\circ} \mathrm{C}\right)$ for the eclogite 70-AM-10. In addition, they are close to the range $600-700^{\circ} \mathrm{C}$ at which AA eclogitic lenses began to convert to amphibolites (Ernst 1977, Tóth et al, 2000), and agree also with the crystal-chemical features of the amphiboles occurring in sample 70-AM-10 (Bocchio et al. 1978). Indeed, all amphibole grains analyzed with crystallographic techniques display a pargasitic composition and appear to have crystallized at a relatively high temperature, in agreement with their ${ }^{\mathrm{IV}} \mathrm{Al}$ contents (1.55-1.85 apfu). However, they show a wide chemical variation (among different crystals and among different zones in the same crystal) and a partial disorder among cations, indicating that homogenization was prevented. This inference further supports the conclusion tentatively suggested by Bocchio et al. (1985) that the main cause of the low values of temperature calculated for eclogite sample 70-AM-10 is a disequilibrium condition, probably related to a second stage of exchange of clinopyroxene with garnet, or with another ferromagnesian phase, during the process of symplectite formation related to the Lepontine event. Alternatively, Bocchio et al. (1985) also argued that such an eclogite might be somehow related to the formation of the chlorite-bearing peridotite mylonite rim around the Alpe Arami body.

The in situ data on the REE and other trace elements obtained in garnet and clinopyroxene in the present work are in agreement with the suggested conditions of disequilibrium. Heterogeneity in trace elements has been observed in several minerals of other occurrences of eclogite in the Alps (Tauern Window: Getty \& Selverstone 1994; Trescolmen: Zack et al. 2001), and it was ascribed to mobilization by $\mathrm{H}_{2} \mathrm{O}$ and other fluids, not only before and during subduction, but also during the early stage of exhumation. This interpretation could be valid also for the eclogites of Alpe Arami. More investigations, both of mineral phases and of a higher number of representative samples from all around peridotite body, could provide a test of this hypothesis.

\section{ACKNOWLEDGEMENTS}

This research was financially supported by FIRST funds (Università degli Studi, Milan) and by National
Research Council at CNR-IDPA (Milan) and CNRIGG (Pavia) where the electron and ion microprobe, respectively, are located. We thank A. Mottana for the availability of sample 70-AM-10 and for critically reading the manuscript at various stages of preparation. The authors are also indebted to F.M. Brouwer and D.E. Jacob for helpful suggestions with the thermobarometric calculations. The final version of the paper has been improved through the careful reviews of E.D. Ghent and E.J.K. Ravna.

\section{REFERENCES}

Agrinier, P., Javoy, M., Smith, D.C. \& Pineau, F. (1985): Carbon and oxygen isotopes in eclogites, amphibolites, veins and marbles from the Western Gneiss region, Norway. Chem. Geol. 52, 145-162.

Anders, E. \& GREvesse, N. (1989): Abundances of the elements: meteoritic and solar. Geochim. Cosmochim. Acta 53, 197-214.

Barnicoat, A.C. \& CARTwright, I. (1997): The gabbroeclogite transformation: an oxygen isotope and petrographic study of west Alpine ophiolites. J. Metamorph. Geol. 15, 93-104.

BECKER, H. (1993): Garnet peridotite and eclogite Sm-Nd mineral ages from the Lepontine dome (Swiss Alps): new evidence for Eocene high-pressure metamorphism in the Central Alps. Geology 21, 599-602.

JOCHUM, K.P. \& CARLSON R.W. (2000): Trace element fractionation during dehydration of eclogites from high-pressure terranes and the implications for element fluxes in subduction zones. Chem. Geol. 163, 65-99.

BocchIo, R. (1975): Le eclogiti retrometamorfiche di Gorduno (Canton Ticino, Svizzera). Per. Mineral. 44, 245-256.

(1977): Ferropargasite alluminifera in un'eclogite di Gorduno (Canton Ticino, Svizzera). Rend. Soc. It. Mineral. Petrol. 33, 519-529.

De Capitani, L., Ottolini, L. \& Cella, F. (2000): Trace element distribution in eclogites and their clinopyroxene/garnet pair: a case study from Soazza (Switzerland). Eur. J. Mineral. 12, 147-161.

, Liborio, G. \& Mottana, A. (1985): Petrology of the amphibolitized eclogites of Gorduno, Lepontine Alps, Switzerland. Chem. Geol. 50, 65-86.

UngaretTi, L. \& Rossi, G. (1978): Crystal chemical characterization of eclogitic amphiboles from Alpe Arami, Lepontine Alps, southern Switzerland. Rend. Soc. It. Mineral. Petrol. 34, 453-469.

Bottazzi, P., Ottolini, L., Vannucci, R. \& Zanetti, A. (1994): An accurate procedure for the quantification of rare earth elements in silicates. In SIMS IX Proceedings (A. Benninghoven, Y. Nihei, N. Shimizu \& H.W. Werner, eds.). John Wiley \& Sons, Chichester, U.K. (927-930) 
BRENKER, F.E. \& BREY, G.P. (1997): Reconstruction of the exhumation path of the Alpe Arami garnet-peridotite body from depths exceeding $160 \mathrm{~km}$. J. Metamorph. Geol. 15, 581-592.

MÜlleR, W.F. \& BREY, G.P. (2003): Variation of antiphase domain size in omphacite: a tool to determine the temperature-time history of eclogites revisited. Am. Mineral. 88, 1300-1311.

Brouwer, F.M. (2000): Thermal evolution of high-pressure metamorphic rocks in the Alps. Geol. Ultraiectina (Univ. Utrecht) 199.

CAPORuscio, F.A. (1990): Oxygen isotope systematics of eclogite mineral phases from South Africa. Lithos 25, 203210 .

\& SMYTH, J.R. (1990): Trace element crystal chemistry of mantle eclogites. Contrib. Mineral. Petrol. 105, $550-561$.

CARPENTER, M.A. (1981): Time-temperature transition (TTT) analysis of cation disordering in omphacite. Contrib. Mineral. Petrol. 71, 443-440.

Champness P.E. (1973): Speculation on an order-disorder transformation in omphacite. Am. Mineral. 58, 540-542.

Dal Vesco, E. (1953): Genesi e metamorfosi delle rocce basiche e ultrabasiche nell'ambiente mesozonale dell'orogene Pennidico: studio geologico-petrografico della catena Gaggio-Basal (cantone Ticino). Schweiz. Mineral. Petrogr. Mitt. 33, 173-480.

DobrZhinetSkAYA, L.F., GreEN, H.W., II \& WANG, Su (1996): Alpe Arami: a peridotite massif from depths of more than 300 kilometers. Science 271, 1841-1845.

, Schweinehage, R., Massonne, H.-J. \& Green, H.W. (2002): Silica precipitates in omphacite from eclogite at Alpe Arami, Switzerland: evidence of deep subduction. J. Metamorph. Geol. 20, 481-492.

Ellis, D.J. \& Green, D.H. (1979): An experimental study of the effect of $\mathrm{Ca}$ upon garnet-clinopyroxene $\mathrm{Fe}-\mathrm{Mg}$ exchange equilibria. Contrib. Mineral. Petrol. 71, 13-22.

ERNST, W.G. (1977): Mineralogic study of eclogitic rocks from Alpe Arami, Lepontine Alps, southern Switzerland. J. Petrol. 18, 371-398.

(1981): Petrogenesis of eclogites and peridotites from the Western and Ligurian Alps. Am. Mineral. 66, 443-472.

Frondel, C. (1968): Crystal chemistry of scandium as a trace element in minerals. Z. Kristallogr. 127, 121-138.

GEBAUER, D. (1999): Alpine geochronology of the Central and Western Alps: new constraints for a complex geodynamic evolution. Schweiz. Mineral. Petrogr. Mitt. 79, 191-208.
GetTy, S.R. \& Selverstone, J. (1994): Stable isotopic and trace element evidence for restricted fluid migration in 2 GPa eclogites. J. Metamorph. Geol. 12, 747-760.

Goldschmidt, V.M. \& Peters, C. (1931): Zur Geochemie des Scandiums. Nachr. Gess. Wiss. Göttingen, Math.-Phys. Kl.

GRAUCH, R.I. (1989): Rare earth elements in metamorphic rocks. In Geochemistry and Mineralogy of Rare Earth Elements (B.R. Lipin \& G.A. McKay, eds.). Rev. Mineral. 21, 147-167.

Green, H.W., II, Dobrzhinetskaya, L. \& Bozhilov, K. (1997a): Determining the origin of ultra-high pressure lherzolites (response). Science 278, 704-707.

RigGs, E.M. \& Jin, ZHEN-Ming (1997b) Alpe Arami: a peridotite massif from the Mantle Transition Zone? Tectonophysics 279, 1-21.

GRIFFIN, W.L. \& BRUECKNER, H.K. (1985): REE, Rb-Sr and Sm-Nd studies of Norwegian eclogites. In Isotope Geochemistry and Geochronology of Eclogites (D.C. Smith \& P. Vidal, eds.). Chem. Geol. (Isot. Geosci. Sect.) 52, 249-271.

, JaQues, A.L., Sie, S.H., Ryan, C.G., Cousens, D.R. \& SuTER, G.F. (1988): Conditions of diamond growth: a proton microprobe study of inclusions in West Australian diamonds. Contrib. Mineral. Petrol. 99, 143-158.

Grubenmann, U. (1908): Der Granatolivinfels des Gordunotales und seine Begleitgesteine. Viertel-jahrsschr. Naturf. Ges. Zürich, 129-156.

Harte, B. \& Kirkley, M.B. (1997): Partitioning of trace elements between clinopyroxene and garnet: data from mantle eclogites. Chem. Geol. 136, 1-24.

HeINRICH, C.A. (1982): Kyanite-eclogite to amphibolite facies evolution of hydrous mafic and pelitic rocks, Adula Nappe, Central Alps. Contrib. Mineral. Petrol. 81, 30-38.

(1986): Eclogite facies regional metamorphism of hydrous mafic rocks in the Central Alpine Adula Nappe. $J$. Petrol. 27, 123-154.

Hofmann, A.W. (1988): Chemical differentiation of the Earth: the relationship between mantle, continental crust and oceanic crust. Earth Planet. Sci. Lett. 90, 297-314.

JACOB, D.E. \& FOLEY, S.F. (1999): Evidence for Archean ocean crust with low high field strength element signature from diamondiferous eclogite xenoliths. Lithos 48, 317-336.

KoHn, M.J. \& VALLEY, J.W. (1998): Effects of cation substitutions in garnet and pyroxene on equilibrium oxygen isotope fractionations. J. Metamorph. Geol. 16, 625-639.

LEECH, M.L. \& ERNST, W.G. (2000): Petrotectonic evolution of the high- to ultrahigh-pressure Maksyutov Complex, Karayanova area, south Ural Mountains: structural and oxygen isotope constraints. Lithos 52, 235-252. 
Mattey, D., Lowry, D. \& MacPherson, C. (1994): Oxygen isotope composition of mantle peridotite. Earth Planet. Sci. Lett. 128, 231-241.

Messiga, B., Tribuzio, R., Bottazzi, P. \& Ottolini, L. (1995): An ion microprobe study on trace element composition of clinopyroxenes from blueschist and eclogitized $\mathrm{Fe}-\mathrm{Ti}$ gabbros, Ligurian Alps, northwestern Italy: some petrologic considerations. Geochim. Cosmochim. Acta 59, 59-75.

Miller, C., Stosch, H.-G. \& Hoernes, S. (1988): Geochemistry and origin of eclogites from the type locality Koralpe and Saualpe, Eastern Alps, Austria. Chem. Geol. 67, 103118.

Möckel, J.R. (1969): Structural petrology of the garnetperidotite of Alpe Arami (Ticino, Switzerland). Leidse Geol. Meded. 42, 61-130.

Morimoto, N., Fabriès, J., Ferguson, A.K., GinZburg, I.V., Ross, M., Seifert, F.A., Zussman, J., Aoki, K. \& GotTARDI, G. (1988): Nomenclature of pyroxenes. Mineral. Mag. 52, 535-550.

MotTAnA, A. (1986): Crystal-chemical evaluation of garnet and omphacite microprobe analyses: its bearing on the classification of eclogites. Lithos 19, 171-186.

MueHLEnBachs, K. (1986): Alteration of the oceanic crust and the ${ }^{18} \mathrm{O}$ history of seawater. In Stable Isotopes in High Temperature Geological Processes (J.W. Valley, H.P. Taylor, Jr. \& J.R. O’Neil, eds.). Rev. Mineral. 16, 425-444.

\& Clayton, R.N. (1976): Oxygen isotope composition of the oceanic crust and its bearing on seawater. $J$. Geophys. Res. 81, 4365-4369.

Mysen, B.O. (1978): Experimental determination of crystalvapor partition coefficients for rare-earth elements to 30 kbar pressure. Carnegie Inst. Wash., Yearb. 77, 689-695.

Nadeau, S., Philippot, P. \& Pineau, F. (1993): Fluid inclusion and mineral isotopic compositions $(\mathrm{H}-\mathrm{C}-\mathrm{O})$ in eclogitic rocks as tracers of local fluid migration during high-pressure metamorphism. Earth Planet. Sci. Lett. 114, 431-448.

Nimis, P. \& TrommsdorfF, V. (2001a): Revised thermobarometry of Alpe Arami and other garnet peridotites from the Central Alps. J. Petrol. 42, 103-115.

\& (2001b): Comment on "New constraints on the $\mathrm{P}-\mathrm{T}$ evolution of the Alpe Arami garnet peridotite body (Central Alps, Switzerland)" by Paquin \& Altherr (2001). J. Petrol. 42, 1773-1779.

NovaK, G.A. \& GibBs, G.V. (1971): The crystal chemistry of the silicate garnets. Am. Mineral. 56, 791-825.

OBERTI, R. \& CAPORUSCIO, F.A. (1991): Crystal chemistry of clinopyroxenes from mantle eclogites: a study of the key role of the M2 site population by means of crystal-structure refinement. Am. Mineral. 76, 1141-1152.
O'HARA, M.J. \& MERCY, E.L.P. (1966): Garnet-peridotite and eclogite from Bellinzona, Switzerland. Earth Planet. Sci. Lett. 1, 295-300.

Olker, B., AltherR, R. \& PAQuin, J. (2003): Fast exhumation of the ultrahigh-pressure Alpe Arami garnet peridotite (Central Alps, Switzerland): constraints from geospeedometry and thermal modelling. J. Metamorph. Geol. 21, 395402.

Ongley, J.S., Basu, A.R. \& Kyser, T.K. (1987): Oxygen isotopes in coexisting garnets, clinopyroxenes and phlogopites of Roberts Victor eclogites: implications for petrogenesis and mantle metasomatism. Earth Planet. Sci. Lett. 83, 8084.

O’REILLY, S.Y. \& GRIFFIN, W.L. (1995): Trace-element partitioning between garnet and clinopyroxene in mantle-derived pyroxenites and eclogites: P-T-X controls. Chem. Geol. 121, 105-130.

Paquin, J. \& Altherr, R. (2001a): New constraints on the PT evolution of the Alpe Arami garnet peridotite body (Central Alps, Switzerland). J. Petrol. 42, 1119-1140.

$\&$ (2001b): 'New constraints on the P-T evolution of the Alpe Arami garnet peridotite body (Central Alps, Switzerland)': reply to comment by Nimis \& Trommsdorff (2001). J. Petrol. 42, 1781-1787.

\& (2002): Subduction-related lithium metasomatism during exhumation of the Alpe Arami ultrahigh-pressure garnet peridotite (Central Alps, Switzerland). Contrib. Mineral. Petrol. 143, 623-640.

Pavese, A., Bocchio, R. \& Ivaldi, G. (2000): In situ high temperature single crystal X-ray diffraction study of a natural omphacite. Mineral. Mag. 64, 983-993.

Diella, V., Levy, D, \& Hanfland, M. (2001): Synchrotron X-ray powder diffraction study of natural $P 2 / n$-omphacites at high-pressure conditions. Phys. Chem. Minerals 28, 9-16.

Pearce, J.A. (1983): A “User Guide" to Basalt Discrimination Diagrams. Open Univ., Milton Keynes, U.K.

\& CANN, J.R. (1973): Tectonic setting of basic volcanic rocks determined using trace element analysis. Earth Planet. Sci. Lett. 19, 290-300.

PfiffNer, M. \& TROMmsdorfF, V. (1998): The high-pressure ultramafic-mafic-carbonate suite of Cima Lunga - Adula, Central Alps: excursion to Cima di Gagnone and Alpe Arami. Schweiz. Mineral. Petrogr. Mitt. 78, 337-354.

RÅHEIM, A. \& GREen, D.H. (1974): Experimental determination of the temperature and pressure dependence of the $\mathrm{Fe}-$ $\mathrm{Mg}$ partition coefficient for coexisting garnet and clinopyroxene. Contrib. Mineral. Petrol. 48, 179-203.

Ravna, K. (2000) : The garnet-clinopyroxene $\mathrm{Fe}^{2+}-\mathrm{Mg}$ geothermometer: an updated calibration. J. Metamorph. Geol. 18, 211-219. 
\& TERRY, M.P. (2004): Geothermobarometry of UHP and HP eclogites and schists - an evaluation of equilibria among garnet - clinopyroxene - kyanite phengite - coesite/quartz. J. Metamorph. Geol. (in press).

Rossi, G., Smith, D.C., Ungaretti, L. \& Domeneghetti, M.C. (1983): Crystal-chemistry and cation ordering in the system diopside-jadeite: a detailed study by crystal structure refinement. Contrib. Mineral. Petrol. 83, 247-258.

, Tazzoli, V. \& Ungaretti, L. (1978): Crystalchemical studies on sodic clinopyroxenes. In Rock-Forming Minerals. Proc. XI Gen. Meeting, Int. Mineral, Assoc., 20-45.

Rost, F. \& GRIGEL, W. (1964): Über accessorische Elemente in mitteleuropäischen Eklogiten und ihren Mineralien. Geochim. Cosmochim. Acta 28, 1933-1951.

Schmidt, R., Wilke, M., Oberhänsli, R., Janssens, K., Falkenberg, G., Franz, L. \& GaAb, A. (2003): MicroXANES determination of ferric iron and its application in thermobarometry. Lithos 70, 381-392.

ShanNON, R.D. (1976): Revised effective ionic radii and systematic studies of interatomic distances in halides and chalcogenides. Acta Crystallogr. A32, 751-767.

Shatsky, V.S., Kozmenko, O.A. \& Sobolev, N.V. (1990): Behaviour of rare-earth elements during high-pressure metamorphism. Lithos 25, 219-226.

Shearer, C.K., PAPIKe, J.J., Simon, S.B. \& Shimizu, N. (1989): An ion microprobe study of the intra-crystalline behavior of REE and selected trace elements in pyroxene from mare basalts with different cooling and crystallization histories. Geochim. Cosmochim. Acta 53, 1041-1054.

Sobolev, V.N., McCammon, C.A., Taylor, L.A., Snyder, G.A. \& Sobolev, N.V. (1999): Precise Mössbauer milliprobe determination of ferric iron in rock-forming minerals and limitations of electron microprobe analysis. Am. Mineral. 84, 78-85.
Sun, S.S. \& McDonOugH, W.F. (1989): Chemical and isotopic systematics of oceanic basalts: implications for mantle composition and processes. In Magmatism in the Ocean Basins (A.D. Saunders \& M.J. Norry, eds.). Geol. Soc., Spec. Publ. 42, 313-345.

Tóth, T.M., Grandjean, V. \& Engi, M. (2000): Polyphase evolution and reaction sequence of compositional domains in metabasalt: a model based on local chemical equilibrium and metamorphic differentiation. Geol. J. 35, 163-183.

Tribuzio, R., Vannucci, R., Bottazzi, P.\& Ottolini, L. (1994): Residence of REE in low-temperature eclogites from Ligurian Alps, north western Italy: the role of accessory minerals. Mineral. Mag. 58A, 912-913.

Vogel, D.E. \& GARLICK, G.D. (1970): Oxygen-isotope ratios in metamorphic eclogites. Contrib. Mineral. Petrol. 28, 183-191.

Woodland, A.B., Seitz, H.-M., Altherr, R., Marschall, H., OLKER, B.\& LuDWIG, T. (2002): Li abundances in eclogite minerals: a clue to a crustal or mantle origin? Contrib. Mineral. Petrol. 143, 587-601.

ZACK, T., Rivers, T. \& Foley, S.F. (2001): Cs-Rb-Ba systematics in phengite and amphibole: an assessment of fluid mobility at $2.0 \mathrm{GPa}$ in eclogites from Trescolmen, Central Alps. Contrib. Mineral. Petrol. 140, 651-669.

Zheng, Yong-FeI (1993): Calculation of oxygen isotope fractionation in anhydrous silicate minerals. Geochim. Cosmochim. Acta 57, 1079-1091.

Fu, Bin, Gong, Bing \& Li, Shuguang (1996): Extreme ${ }^{18} \mathrm{O}$ depletion in eclogite from the $\mathrm{Su}-\mathrm{Lu}$ terrane in East China. Eur. J. Mineral. 8, 317-323.

Received December 21, 2003, revised manucript accepted May 28, 2004. 